\title{
Green tea catechin, epigallocatechin-3-gallate, attenuates the cell viability of human non-small-cell lung cancer A549 cells via reducing Bcl-xL expression
}

\author{
JUN-ICHIRO SONODA ${ }^{1}$, RYUJI IKEDA ${ }^{2}$, YASUTAKA BABA ${ }^{3}$, KEIKO NARUMI ${ }^{1}$, \\ AKIO KAWACHI ${ }^{1}$, ERISA TOMISHIGE ${ }^{1}$, KAZUYA NISHIHARA ${ }^{1}$, YASUO TAKEDA ${ }^{2}$, \\ KATSUSHI YAMADA ${ }^{4}$, KEIZO SATO ${ }^{5}$ and TOSHIRO MOTOYA ${ }^{1}$
}

\begin{abstract}
${ }^{1}$ First Department of Clinical Pharmacy, School of Pharmaceutical Sciences, Kyushu University of Health \& Welfare, Nobeoka, Miyazaki 882-8508; Departments of ${ }^{2}$ Clinical Pharmacy and Pharmacology and ${ }^{3}$ Radiology, Graduate School of Medical and Dental Sciences, Kagoshima University, Sakuragaoka, Kagoshima 890-8520; ${ }^{4}$ Department of Clinical Pharmacology, Faculty of Pharmaceutical Science, Nagasaki International University, Sasebo, Nagasaki 859-3298; ${ }^{5}$ Department of Clinical Biochemistry, School of Pharmaceutical Sciences, Kyushu University of Health \& Welfare, Nobeoka, Miyazaki 882-8508, Japan
\end{abstract}

Received December 18, 2013; Accepted April 29, 2014

DOI: $10.3892 / \mathrm{etm} .2014 .1719$

\begin{abstract}
Clinical and epidemiological studies have indicated that the consumption of green tea has a number of beneficial effects on health. Epigallocatechin-3-gallate (EGCg), the major polyphenolic compound present in green tea, has received much attention as an active ingredient. Among the numerous promising profiles of $\mathrm{EGCg}$, the present study focused on the anticancer effects. Apoptosis induced by EGCg and subsequent cell growth suppression have been demonstrated in a number of cell culture studies. However, the underlying mechanism of apoptotic cell death remains unclear. Thus, the aim of the present study was to identify the major molecule that mediates proapoptotic cell death by EGCg. The effect of EGCg on cell proliferation and the induction of mRNA that modulates apoptotic cell death was evaluated in the A549 human non-small-cell lung cancer cell line. In addition, morphological changes were assessed by microscopy in A549 cells that had been treated with $100 \mu \mathrm{M}$ EGCg for $24 \mathrm{~h}$. The MTT assay revealed that cell proliferation was significantly reduced by EGCg in a dose-dependent manner (3-100 $\mu \mathrm{M})$. The mRNA expression level of B-cell lymphoma-extra large (Bcl-xL) was decreased in A549 cells following $24 \mathrm{~h}$ incubation with $100 \mu \mathrm{M}$ EGCg. Therefore, the results indicated that the inhibition of cell proliferation by
\end{abstract}

Correspondence to: Dr Jun-Ichiro Sonoda, First Department of Clinical Pharmacy, School of Pharmaceutical Sciences, Kyushu University of Health \& Welfare, 1714-1 Yoshino-cho, Nobeoka, Miyazaki 882-8508, Japan

E-mail: son@phoenix.ac.jp

Key words: epigallocatechin-3-gallate, A549 cells, B-cell lymphoma-extra large, apoptosis
EGCg may be achieved via suppressing the expression of the cell death-inhibiting gene, Bcl-xL.

\section{Introduction}

Green tea (Camellia sinensis) is one of the most popular beverages worldwide, and contains a large amount of flavonoids, predominantly catechins, including epicatechin, its hydroxyl derivative epigallocatechin, and their gallic acid esters, epicatechin-3-gallate and epigallocatechin-3-gallate (EGCg; Fig. 1). Among these catechins, EGCg is an abundant constituent of green tea (leaf) and has been shown to exhibit antioxidative, anticarcinogenic and anticancer effects in vitro. The polyphenolic structure of these compounds exerts antioxidative effects by trapping reactive oxygen species (ROS). It was previously demonstrated that daily intake of green tea reduced oxidative stress in vivo (1). In addition, against a background of increasing public health concerns, it has been hypothesized that green tea consumption has beneficial effects against various pathological conditions, including cardiovascular disease, diabetes and cancer.

Green tea catechins, in particular, have attracted attention as cancer-preventive agents due to their low toxicity and ready availability to the general population, as well as exerting preventive effects against cancers in humans (2-5). A prospective cohort study on a Japanese population demonstrated that green tea has a strong potency in preventing cancers in a variety of organs (6). Additional epidemiological or clinical studies revealed that green tea consumption is inversely associated with the progression of prostate cancer, the risk of hematological malignancies and the risk of breast cancer recurrence, among others (7-9). In cells cultured for in vitro experiments on green tea catechins, growth inhibition and apoptosis induction have been observed in a variety of cell lines $(10,11)$. Previously, using two cell lines, peripheral 
<smiles>Oc1cc(O)c2c(c1)O[C@H](c1ccc(O)c(O)c1)[C@H](O)C2</smiles>

Epicatechin

(EC)<smiles>O=C(O[C@H]1Cc2c(O)cc(O)cc2O[C@@H]1c1ccc(O)c(O)c1)c1cc(O)c(O)c(O)c1</smiles>

Epicatechin-3-gallate (ECg)<smiles>Oc1cc(O)c2c(c1)O[C@H](c1cc(O)c(O)c(O)c1)[C@H](O)C2</smiles>

\section{Epigallocatechin} (EGC)<smiles>O=C(Oc1cc(O)c(O)c(O)c1)[C@H]1Cc2c(O)cc(O)cc2O[C@@H]1c1cc(O)c(O)c(O)c1</smiles>

Epigallocatechin-3-gallate (EGCg)

Figure 1. Chemical structures of green tea catechins.

blood T lymphocytes of adult T-cell leukemia patients and human T-cell leukemia virus type 1 (HTLV-1)-infected T-cell line, it was demonstrated that EGCg inhibited cell growth concomitant with the induction of apoptosis, and was responsible for suppressing the expression of HTLV-1 pX mRNA, which encodes the oncoprotein, Tax (12). Tax protein plays an important role in HTLV-1-infected T-cell leukemogenesis by mediating interactions with transcription factors, including nuclear factor $(\mathrm{NF})-\kappa \mathrm{B}$. In the CTLL-2 Tax-expressing mouse T-cell line, constitutive expression of B-cell lymphoma-extra large $(\mathrm{Bcl}-\mathrm{xL})$ via the $\mathrm{NF}-\kappa \mathrm{B}$ pathway has been shown to contribute to the inhibition of apoptosis (13).

Several cell culture studies have focused on one of the hallmarks of the decrease in cell growth by green tea catechins, namely, the suppression of $\mathrm{NF}-\kappa \mathrm{B}$ activation and the subsequent induction of apoptosis. However, in vivo evidence remains limited and no definitive conclusions have yet been drawn. Ahmad et al revealed that EGCg reversed the degradation of $\mathrm{I} \kappa \mathrm{B} \alpha$ protein, which specifically inhibits $\mathrm{NF}-\kappa \mathrm{B}$ activation, and subsequently downregulated cell cycle deregulation and the induction of apoptosis in A431 human epidermoid carcinoma cells (14). An in vivo interventional study revealed that intake of green tea extract capsules diminished the HTLV-1 provirus load in peripheral blood lymphocytes of asymptomatic HTLV-1 carriers. Therefore, it was hypothesized that the decrease in HTLV-1 provirus load was caused by EGCg stabilizing $\mathrm{I} \kappa \mathrm{B}$ and abrogating $\mathrm{NF}-\kappa \mathrm{B}$ activation in HTLV-1 carrier lymphocytes following the intake of capsules (15).

An increase in the level of nuclear translocation or constitutive activation of $\mathrm{NF}-\kappa \mathrm{B}$ has been attributed to the induction of prosurvival gene products, including $\mathrm{Bcl}-2$ and $\mathrm{Bcl}-\mathrm{xL}(16,17)$. Bcl-xL, a member of the Bcl-2 family, inhibits apoptosis by blocking the release of cytochrome $c$ from the mitochondria. A decrease in $\mathrm{Bcl}-\mathrm{xL}$ gene expression may lead to the promotion of cell death. However, the events downstream of $\mathrm{NF}-\kappa \mathrm{B}$ inactivation by catechins are not clear.

Among green tea catechins, EGCg has been shown to exhibit optimal anticancer activity, which is associated with the number of -OH groups. Therefore, in the present study,
EGCg was adopted as a well-characterized model catechin. The aim of the present study was to identify the major molecule that mediates proapoptotic cell death by EGCg. To achieve this objective, the A549 human non-small-cell lung cancer cell line was used and the effect of EGCg on cell proliferation and the induction of mRNA that modulates apoptotic cell death was evaluated.

\section{Materials and methods}

Chemicals and reagents. EGCg was purchased from Funakoshi Co., Ltd. (Tokyo, Japan). RPMI-1640 medium and 100X Antibiotic-Antimycotic were obtained from Invitrogen Life Technologies (Carlsbad, CA, USA), while fetal bovine serum (FBS) was purchased from Thermo Scientific Fisher (Waltham, MA, USA). Reverse transcription polymerase chain reaction (RT-PCR) was performed with the SuperScript One-Step RT-PCR with Platinum Taq kit (Invitrogen Life Technologies) and total RNA was extracted using TRIzol reagent (Invitrogen Life Technologies). MTT assay kit was obtained from Roche Diagnostics (Indianapolis, IN, USA). EGCg was dissolved in phosphate-buffered saline (PBS) as a $2 \mathrm{mM}$ stock solution and then stored at $-30^{\circ} \mathrm{C}$.

Cell lines and cell culture. A human non-small-cell lung cancer cell line, A549, was provided by Professor Akiyama from the Department of Molecular Oncology at the Graduate School of Medical and Dental Sciences (Kagoshima University, Kagoshima, Japan). A549 cells were grown in RPMI-1640 medium supplemented with 10\% FBS and Antibiotics-Antimycotics in a $5 \% \mathrm{CO}_{2}$ humidified atmosphere at $37^{\circ} \mathrm{C}$.

Determination of cell survival using the MTT assay. Chemosensitivity was measured in vitro using the MTT colorimetric assay, which was performed in 96-well plates (18). To determine the effect of EGCg, A549 cells $\left(2.5 \times 10^{3}\right)$ in $90 \mu 1$ culture medium were inoculated into each well. Following $24 \mathrm{~h}$ incubation, $10-\mu \mathrm{l}$ samples of various concentrations 
A

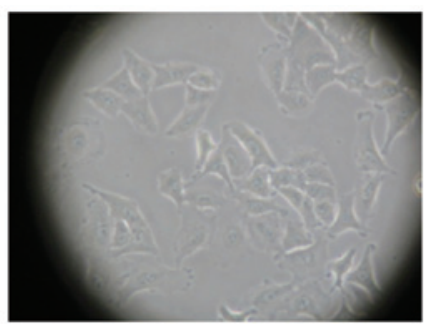

Control
B

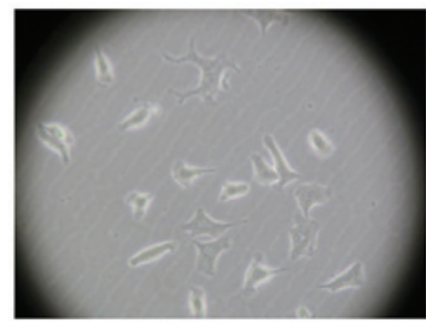

$\operatorname{EGCg}(25 \mu \mathrm{M})$

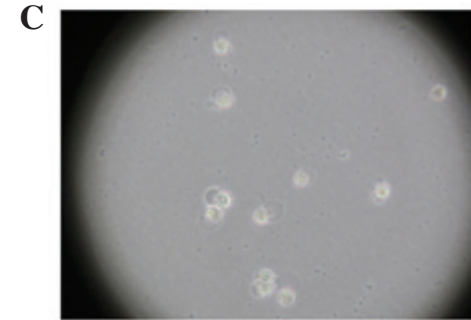

$\operatorname{EGCg}(100 \mu \mathrm{M})$

Figure 2. Effect of EGCg on the morphology of A549 cells. Representative morphology of A549 cells was microscopically observed in (A) control and following co-culture with (B) $25 \mu \mathrm{M}$ and (C) $100 \mu \mathrm{M}$ EGCg. EGCg, epigallocatechin-3-gallate.

of EGCg and the vehicle were added and the plate was incubated for $72 \mathrm{~h}$. Next, $0.5 \mathrm{mg} / \mathrm{ml}$ MTT (final concentration) was added to each well and the plate was incubated for a further $4 \mathrm{~h}$ at $37^{\circ} \mathrm{C}$. The resulting formazan was dissolved in $100 \mu 1$ solubilization solution (10\% SDS in $0.01 \mathrm{M} \mathrm{HCl})$ and the plate was re-incubated overnight at $37^{\circ} \mathrm{C}$. The optical density (OD) at $550 \mathrm{~nm}$ was determined using an ARVO SX model 1420 Multilabel Counter (PerkinElmer, Waltham, MA, USA). The control wells were set as zero absorbance. The percentage of cell survival was calculated using the background-corrected absorbance as follows: Cell survival $(\%)=\left(\mathrm{OD}_{\text {experiment }} / \mathrm{OD}_{\text {control }}\right) \times 100$. The data represent the mean and standard deviation from triplicate determination.

$R T-P C R$. Total cellular RNA was extracted using TRIzol reagent, according to the manufacturer's instructions. RT-PCR was performed with the SuperScript One-Step RT-PCR system and gene-specific primers, according to the manufacturer's instructions. The reaction mixture contained $500 \mathrm{ng}$ total RNA, $0.2 \mathrm{mM}$ dNTPs, $0.2 \mu \mathrm{M}$ each primer and the enzyme mixture, including SuperScript II RT, Platinum Taq DNA polymerase and 1X buffer with $1.2 \mathrm{mM}$ $\mathrm{MgSO}_{4}$. The mixture was maintained at $50^{\circ} \mathrm{C}$ for $20 \mathrm{~min}$, $94^{\circ} \mathrm{C}$ for 2 min and then PCR was performed as follows: 30 cycles at $94^{\circ} \mathrm{C}$ for $15 \mathrm{sec}, 55^{\circ} \mathrm{C}$ for $30 \mathrm{sec}$ and $70^{\circ} \mathrm{C}$ for $30 \mathrm{sec}$. The primers for RT-PCR were designed on the basis of the human sequences in GenBank. These sequences used the following primers: $\mathrm{Bcl}-\mathrm{xL}$ primer forward, 5'-CGGTGAATGGAGCCACTGACCA-3' and reverse, 5'-GCCATCCAAGCTGCGATCCGAC-3'; GAPDH forward, 5'-AGAACATCATCCCTGCCTCTACTGG-3' and reverse, 5'-AAAGGTGGAGGAGTGGGTGTCGCTG-3'.

Statistical analysis. Data from MTT assay were presented as the mean \pm standard deviation of triplicate determinations. Statistical difference was analyzed using a one-way analysis of variance (ANOVA) followed by Dunett's test. SPSS software (SPSS Inc., Chicago, IL, USA) was used and $\mathrm{P}<0.05$ was considered to indicate a statistically significant result.

\section{Results}

Effect of EGCg on the proliferation of A549 cells. Morphological changes in A549 cells were shown to be dependent on the EGCg concentration. Cells exhibited a shape representative of A549 cells in the control ( $24 \mathrm{~h}$ incubation),

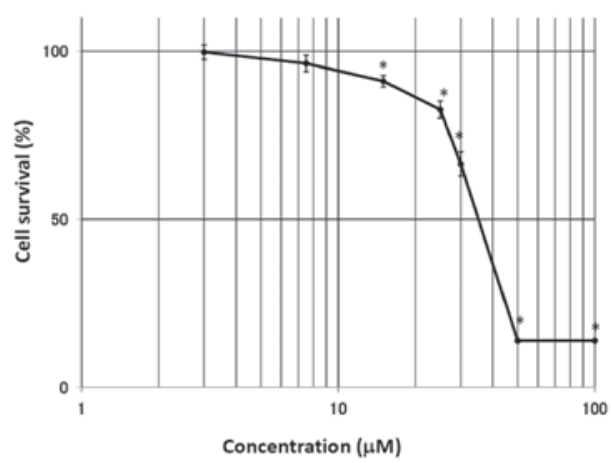

Figure 3. Effect of EGCg on A549 cell survival in the absence or presence of EGCg (3-100 $\mu \mathrm{M})$, as determined by an MTT assay. Points represent the mean of triplicate determination and the bars show the standard deviation. EGCg, epigallocatechin-3-gallate. *Significant reduction compared with control (0 mM EGCg).

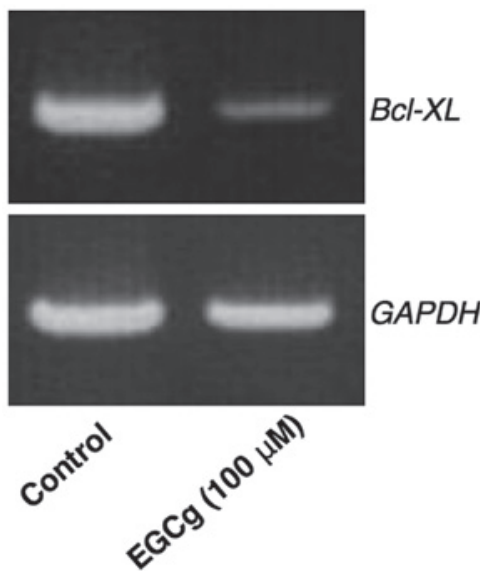

Figure 4. Effect of EGCg on the expression of Bcl-xL in A549 cells, as determined by RT-PCR analysis. Representative image showing the Bcl-xL and GAPDH mRNA expression levels in the absence or presence of $100 \mu \mathrm{M}$ EGCg. EGCg, epigallocatechin-3-gallate; Bcl-xL, B-cell lymphoma-extra large; RT-PCR, reverse transcription polymerase chain reaction.

whereas the cells lost their adhesion ability when treated with $25 \mu \mathrm{M}$ EGCg. When treated with $100 \mu \mathrm{M}$ ECGg, the cells were observed to float in the medium, exhibiting cell death (Fig. 2). The MTT assay was performed at $48 \mathrm{~h}$ after treatment with EGCg in the A549 cells. As shown in Fig. 3, the survival rate in the A549 cells was significantly suppressed by treatment with EGCg. The cell viability rate was markedly reduced at EGCg concentrations $>25 \mu \mathrm{M}$, reaching a plateau 
at $50 \mu \mathrm{M}$. The $\mathrm{IC}_{50}(50 \%$ inhibition of cell growth) for $\mathrm{EGCg}$ in the A549 cells was $36.0 \mu \mathrm{M}$.

Effect of EGCg on the mRNA expression of Bcl-xL in A549 cells. Intracellular $\mathrm{Bcl}-\mathrm{xL}$ expression was analyzed since this protein strongly inhibits apoptosis. If cytosolic Bcl-xL mRNA expression was suppressed by EGCg, the target cells should be induced to undergo apoptosis. The effect of EGCg on the expression of Bcl-xL in A549 cells is shown in Fig. 4. EGCg $(100 \mu \mathrm{M})$ was shown to suppress the mRNA expression of Bcl-xL in A549 cells at $24 \mathrm{~h}$ following administration.

\section{Discussion}

In the present study, EGCg was demonstrated to markedly inhibit cell proliferation at concentrations between 25 and $100 \mu \mathrm{M}$ (Fig. 3), and decrease Bcl-xL mRNA expression under the same conditions at $100 \mu \mathrm{M}$ (Fig. 4) in A549 cells. EGCg has been reported to inhibit the activation of NF- $\mathrm{KB}$ (14), and the activation of NF- $\mathrm{KB}$ leads to the inhibition of apoptosis. $\mathrm{NF}-\kappa \mathrm{B}$ is a heterodimer consisting of two proteins, p65 and p50. In unstimulated cells, NF-kB is located in the cytoplasm and is bound to $\mathrm{I} \kappa \mathrm{B} \alpha$ and $\mathrm{I} \kappa \mathrm{Bb}$, which prevents the molecule from entering the nucleus. External stimuli modulate signal transduction pathways leading to I $\kappa$ B phosphorylation, causing its rapid degradation by proteasomes. The release of NF- $\kappa \mathrm{B}$ from I $\mathrm{KB}$ results in translocation to the nucleus, where NF- $\kappa \mathrm{B}$ binds to a specific sequence in the promoter regions of target genes of antiapoptotic proteins, including Bcl-xL. Therefore, the results of the present study indicate that EGCg reduces the expression of the death-inhibiting gene, Bcl-xL, consequently inducing apoptosis in A549 cells.

Although green tea catechins have been shown to reduce the risk of cardiovascular disease and certain types of cancer, as well as promote physiological functions, including body weight control and antihypertensive, antibacterial, antiviral and neuroprotective effects (19), the present study focused on the anticancer effect of EGCg. On the basis of recent observations, green tea catechins were assumed to exhibit three beneficial properties against cancer.

Firstly, green tea catechins, predominantly EGCg, have potent antioxidant activity and may reduce adverse events associated with pro-oxidant anticancer agents. Generally, anthracyclins and a platinum agent (cisplatin) are considered to release ROS and cause unique side effects, namely, cardiac toxicity and renal dysfunction, respectively. Green tea catechins have been shown to protect against normal cell damage from ROS. Previously, it was demonstrated that daily intake of green tea tablets containing $474 \mathrm{mg}$ catechins significantly reduced the oxidative stress induced by hepatic arterial infusion of cisplatin and 5-fluorouracil in patients with metastatic liver cancer or hepatocellular carcinoma (1). It has also been indicated that administration of EGCg together with pro-oxidant anticancer agents is useful in minimizing adverse effects $(20,21)$. In Japan, cisplatin combination regimens have been considered as standard chemotherapy for non-small cell lung cancer (NSCLC) (22). We hypothesized that conventional chemotherapy combined with green tea catechins may be useful for enhancing their anticancer effectiveness and reducing their adverse drug reactions. Therefore the A549 cell line, which is derived from NSCLC, was adopted in this study assuming lung cancer therapy.

Secondly, EGCg has shown the reverse property against multidrug resistance (MDR). Upon exposure to one chemotherapeutic agent in a clinical context, cancer cells may acquire resistance to chemotherapy. Overexpression of efflux transporters, including P-glycoprotein (P-gp), multidrug-resistance-associated protein 1 and breast cancer resistance protein, has been shown to be a major cause of MDR. Green tea catechins are one type of candidate agent for an effective MDR modulator since they exhibit few side effects and are consumed routinely by a number of people, as a therapeutic aid. A previous study demonstrated that EGCg reversed a doxorubicin-resistant model of hepatocellular carcinoma by inhibiting P-gp pump function (23).

Finally, the most crucial feature is that green tea catechins themselves possess anticancer activity. The present study demonstrated that EGCg significantly reduced A549 cell proliferation at a concentration of $100 \mu \mathrm{M}$. Numerous studies on a wide variety of histological types of cancer, including prostate, breast, colorectal, esophageal, stomach and pancreatic cancer, have also documented the anticancer effects of green tea catechins in experimental and clinical studies, as well as in population-based studies (24-32).

Numerous cell-culture studies have revealed that green tea catechins, particularly EGCg, exert growth inhibition and apoptosis induction effects. Apoptotic cell death is mediated by regulator proteins, including Fas ligand, tumor necrosis factor- $\alpha, \mathrm{CD} 95, \mathrm{NF}-\mathrm{\kappa B}$, apoptotic protease activating factor 1 (Apaf-1), caspases and the Bcl-2 family (Bcl-2, Bcl-xL, Bax and $\mathrm{Bad})$. In human cancer cell lines, it has been demonstrated that $\left[{ }^{3} \mathrm{H}\right] \mathrm{EGCg}$ or fluorescein isothiocyanate-conjugated EGCg is incorporated into the cytosol and the nucleus in a time-dependent manner $(33,34)$. The structure of EGCg was shown to be preserved in the cytosol following identification with a high performance liquid chromatography-electrochemical detector with a reversed-phase column, and the retention time of cytosolic EGCg matched that of standard EGCg (35). Thus, antiapoptotic function evoked by EGCg may be localized in the cytosol, and EGCg may interact with intracellular

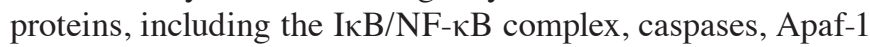
and the Bcl-2 family (Bcl-xL, Bcl-2, Bax and Bad). Certain studies have demonstrated that $\mathrm{EGCg}$ inactivates NF- $\kappa \mathrm{B}$, which consequently induces apoptosis $(14,36)$. The present study attempted to identify a common molecule that is closely associated with apoptosis induction by EGCg, and we hypothesize that the decrease in $\mathrm{Bcl}-\mathrm{xL}$ expression levels is accompanied with the downstream inactivation of NF- $\kappa$ B. The expression levels of antiapototic protein, $\mathrm{Bcl}-\mathrm{xL}$, have been shown to be regulated by the NF- $\mathrm{KB}$ transcription factor in a wide spectrum of cells $(10,13,37)$. In the present study, Bcl-xL mRNA expression levels were shown to be reduced following treatment with EGCg in A549 cells.

In conclusion, the results of the present study demonstrate that the inhibition of cell proliferation by EGCg may occur via the suppression of cell death-inhibiting gene expression. Bcl-xL mRNA expression levels decreased following EGCg administration in non-small-cell lung cancer A549 cells. The observations indicate that green tea may be useful as an antitumor agent to enhance the efficacy of cancer therapy. Although 
the balance between the expression levels of death-inhibiting genes (Bcl-xL and Bcl-2) and death-promoting genes (Bax and $\mathrm{Bad}$ ) is critically important in the regulation of apoptosis, whether EGCg affects Bcl-2, Bax or Bad gene expression is unclear at present. Thus, further studies investigating whether EGCg regulates the gene expression of Bcl-2 family members other than $\mathrm{Bcl}-\mathrm{xL}$ are required.

\section{Acknowledgements}

The authors thank Dr Hisahiro Kai and Dr Tomohiro Shinya (Kyushu University of Health and Wealthfare) for their technical assistance.

\section{References}

1. Baba Y, Sonoda JI, Hayashi S, et al: Reduction of oxidative stress in liver cancer patients by oral green tea polyphenol tablets during hepatic arterial infusion chemotherapy. Exp Ther Med 4: 452-458, 2012.

2. Lee IP, Kim YH, Kang MH, et al: Chemopreventive effect of green tea (Camellia sinensis) against cigarette smoke-induced mutations (SCE) in humans. J Cell Biochem Suppl 27: 68-75, 1997.

3. Shimizu M, Fukutomi Y, Ninomiya M, et al: Green tea extracts for the prevention of metachronous colorectal adenomas: a pilot study. Cancer Epidemiol Biomarkers Prev 17: 3020-3025, 2008.

4. Khan N, Adhami VM and Mukhtar H: Review: green tea polyphenols in chemoprevention of prostate cancer: preclinical and clinical studies. Nutr Cancer 61: 836-841, 2009.

5. Suganuma M, Saha A and Fujiki H: New cancer treatment strategy using combination of green tea catechins and anticancer drugs. Cancer Sci 102: 317-323, 2011.

6. Imai K, Suga K and Nakachi K: Cancer-preventive effects of drinking green tea among a Japanese population. Prev Med 26: 769-775, 1997.

7. Inoue M, Tajima K, Mizutani M, et al: Regular consumption of green tea and the risk of breast cancer recurrence: follow-up study from the Hospital-based Epidemiologic Research Program at Aichi Cancer Center (HERPACC), Japan. Cancer Lett 167: $175-182,2001$

8. Bettuzzi S, Brausi M, Rizzi F, et al: Chemoprevention of human prostate cancer by oral administration of green tea catechins in volunteers with high-grade prostate intraepithelial neoplasia: a preliminary report from a one-year proof-of-principle study. Cancer Res 66: 1234-1240, 2006.

9. Naganuma T, Kuriyama S, Kakizaki M, et al: Green tea consumption and hematologic malignancies in Japan: the Ohsaki study. Am J Epidemiol 170: 730-738, 2009.

10. Nishikawa T, Nakajima T, Moriguchi M, et al: A green tea polyphenol, epigalocatechin-3-gallate, induces apoptosis of human hepatocellular carcinoma, possibly through inhibition of Bcl-2 family proteins. J Hepatol 44: 1074-1082, 2006.

11. Yamauchi R, Sasaki K and Yoshida K: Identification of epigallocatechin-3-gallate in green tea polyphenols as a potent inducer of p53-dependent apoptosis in the human lung cancer cell line A549. Toxicol In Vitro 23: 834-839, 2009.

12. Li HC, Yashiki S, Sonoda J, et al: Green tea polyphenols induce apoptosis in vitro in peripheral blood $\mathrm{T}$ lymphocytes of adult T-cell leukemia patients. Jap J Cancer Res 91: 34-40, 2000.

13. Tsukahara T, Kannagi M, Ohashi T, et al: Induction of Bcl-x(L) expression by human T-cell leukemia virus type 1 Tax through NF-kappaB in apoptosis-resistant T-cell transfectants with Tax. J Virol 73: 7981-7987, 1999.

14. Ahmad N, Gupta S and Mukhtar H: Green tea polyphenol epigallocatechin-3-gallate differentially modulates nuclear factor $\kappa \mathrm{B}$ in cancer cells versus normal cells. Arch Biochem Biophys 376: 338-346, 2000

15. Sonoda J, Koriyama C, Yamamoto S, et al: HTLV-1 provirus load in peripheral blood lymphocytes of HTLV-1 carriers is diminished by green tea drinking. Cancer Sci 95: 596-601, 2004

16. Khoshnan A, Tindell C, Laux I, et al: The NF-kappa B cascade is important in Bcl-xL expression and for the anti-apoptotic effects of the CD28 receptor in primary human CD4+ lymphocytes. J Immunol 165: 1743-1754, 2000.
17. Bui NT, Livolsi A, Peyron JF and Prehn JH: Activation of nuclear factor kappaB and Bcl-x survival gene expression by nerve growth factor requires tyrosine phosphorylation of IkappaBalpha. J Cell Bio 152: 753-764, 2001

18. Carmichael J, DeGraff WG, Gazdar AF Minna JD and Mitchell JB: Evaluation of a tetrazolium-based semiautomated colorimetric assay: assessment of chemosensitivity testing. Cancer Res 47: 936-942, 1987.

19. Cabrera C, Artacho R and Giménez R: Beneficial effects of green tea - a review. J Am Coll Nutr 25: 79-99, 2006.

20. Yamamoto T, Staples J, Wataha J, et al: Protective effects of EGCG on salivary gland cells treated with gamma-radiation or cis-platinum(II)diammine dichloride. Anticancer Res 24 , 3065-3073, 2004.

21. Zheng J, Lee HC, Bin Sattar MM, Huang Y and Bian JS: Cardioprotective effects of epigallocatechin-3-gallate against doxorubicin-induced cardiomyocyte injury. Eur J Pharmacol 652: 82-88, 2011.

22. Ohe Y, Ohashi Y, Kubota K, et al: Randomized phase III study of cisplatin plus irinotecan versus carboplatin plus paclitaxel, cisplatin plus gemcitabine, and cisplatin plus vinorelbine for advanced non-small-cell lung cancer: Four-Arm Cooperative Study in Japan. Ann Oncol 18: 317-323, 2007.

23. Liang G, Tang A, Lin X, et al: Green tea catechins augment the antitumor activity of doxorubicin in an in vivo mouse model for chemoresistant liver cancer. Int J Oncol 37: 111-123, 2010.

24. Kurahashi N1, Sasazuki S, Iwasaki M, Inoue M, Tsugane S; JPHC Study Group: Green tea consumption and prostate cancer risk in Japanese men: a prospective study.. Am J Epidemiol 167: 71-77, 2008

25. Paschka AG, Butler R and Young CY: Induction of apoptosis in prostate cancer cell lines by the green tea component, (-)-epigallocatechin-3-gallate. Cancer Lett 130: 1-7, 1998.

26. Fujiki H: Two stages of cancer prevention with green tea. J Cancer Res Clin Oncol 125: 589-597, 1999.

27. Inoue M, Tajima K, Mizutani M, Iwata H, Iwase T, Miura S, Hirose K, Hamajima N and Tominaga S: Regular consumption of green tea and the risk of breast cancer recurrence: follow-up study from the Hospital-based Epidemiologic Research Program at Aichi Cancer Center (HERPACC), Japan. Cancer Lett 167: 175-182, 2001.

28. Orner GA, Dashwood WM, Blum CA, Díaz GD, Li Q and Dashwood RH: Suppression of tumorigenesis in the Apc(min) mouse: down-regulation of beta-catenin signaling by a combination of tea plus sulindac. Carcinogenesis 24: 263-267, 2003.

29. Gao YT, McLaughlin JK, Blot WJ, Ji BT, Dai Q and Fraumeni JF Jr: Reduced risk of esophageal cancer associated with green tea consumption. J Natl Cancer Inst 86: 855-858, 1994.

30. Hibasami H, Komiya T, Achiwa Y, Ohnishi K, Kojima T, Nakanishi K, Akashi K and Hara Y: Induction of apoptosis in human stomach cancer cells by green tea catechins. Oncol Rep 5: 527-529, 1998.

31. Takada M, Nakamura Y, Koizumi T, Toyama H, Kamigaki T, Suzuki Y, Takeyama Y and Kuroda Y: Suppression of human pancreatic carcinoma cell growth and invasion by epigallocatechin-3-gallate. Pancreas 25: 45-48, 2002

32. Fujimoto N, Sueoka N, Sueoka E, Okabe S, Suganuma M, Harada $M$ and Fujiki H: Lung cancer prevention with (-)-epigallocatechin gallate using monitoring by heterogeneous nuclear ribonucleoprotein B1. Int J Oncol 20: 1233-1239, 2002.

33. Okabe S, Suganuma M, Hayashi M, Sueoka E, Komori A and Fujiki H: Mechanisms of growth inhibition of human lung cancer cell line, PC-9, by tea polyphenols. Jap J Cancer Res 88: 639-643, 1997.

34. Lee MH, Han DW, Hyon SH and Park JC: Apoptosis of human fibrosarcoma HT-1080 cells by epigallocatechin-3-O-gallate via induction of $\mathrm{p} 53$ and caspases as well as suppression of $\mathrm{Bcl}-2$ and phosphorylated nuclear factor- $x$ B. Apoptosis 16: 75-85, 2011.

35. Hong J, Lambert JD, Lee SH, Sinko PJ and Yang CS: Involvement of multidrug resistance-associated proteins in regulating cellular levels of (-)-epigallocatechin-3-gallate and its methyl metabolites. Biochem Biophys Res Commun 310: 222-227, 2003.

36. Ahn SC, Kim GY, Kim JH, et al: Epigallocatechin-3-gallate, constituent of green tea, suppresses the LPS-induced phenotypic and functional maturation of murine dendritic cells through inhibition of mitogen-activated protein kinases and NF-kappaB. Biochem Biophys Res Commun 313: 148-155, 2004.

37. Lee HH, Dadgostar H, Cheng Q, Shu J and Cheng G: NF-kappaB-mediated up-regulation of $\mathrm{Bcl}-\mathrm{x}$ and $\mathrm{Bfl}-1 / \mathrm{A} 1$ is required for CD40 survival signaling in B lymphocytes. Proc Natl Acad Sci U S A 96: 9136-9141, 1999. 